\title{
GIS APPROACH TO ESTIMATION OF THE TOTAL PHOSPHOROUS TRANSFER IN THE PILICA RIVER LOWLAND CATCHMENT
}

\author{
Artur Magnuszewski ${ }^{1}$, Edyta KiedrzyŃSKaA ${ }^{2,3}$ Marcin Kiedrzyński ${ }^{4}$, Sharon Moran ${ }^{5}$ \\ ${ }^{1}$ Hydrology Department, University of Warsaw, Poland \\ ${ }^{2}$ European Regional Centre for Ecohydrology, Polish Academy of Sciences, Łódź, Poland \\ ${ }^{3}$ Department of Applied Ecology, University of Łódź, Poland \\ ${ }^{4}$ Department of Geobotany and Plant Ecology, University of Łódź, Poland \\ ${ }^{5}$ Department of Environmental Studies, State University of New York College of Environmental Science and \\ Forestry, Syracuse, USA
}

Manuscript received: May 28, 2014

Revised version: July 28, 2014

\begin{abstract}
MagnusZewski A., KiedrZYŃSKa E., KiedrZYŃSKi M., Moran S., 2014. GIS approach to estimation of the total phosphorous transfer in the Pilica River lowland catchment. Quaestiones Geographicae 33(3), Bogucki Wydawnictwo Naukowe, Poznań, pp. 101-110, 3 tables, 6 figs. DOI 10.2478/quageo-2014-0033, ISSN 0137-477X.

AвsTRACT: In this paper, the Pilica River catchment (central Poland) is analyzed with a focus on understanding the total phosphorous transfer along theriver system whichalso contains thelargeartificialSulejów Reservoir. The paper presents a GIS method for estimating the total phosphorous (TP) load from proxy data representing sub-catchment land use and census data. The modelled load of TP is compared to the actual transfer of TP in the Pilica River system. The results shows that the metrics of connectivity between river system and dwelling areas as well as settlement density in the sub-catchments are useful predictors of the total phosphorous load. The presence of a large reservoir in the middle course of the river can disrupt nutrient transport along a river continuum by trapping and retaining suspended sediment and its associated TP load. Analysis of the indirect estimation of TP loads with the GIS analysis can be useful for identifying beneficial reservoir locations in a catchment. The study has shown that the Sulejów Reservoir has been located in a subcatchment with a largest load of the TP, and this feature helps determine the problem of reservoir eutrphication.
\end{abstract}

KEY WORDS: total phosphorus load, Pilica River catchment, GIS, central Poland.

Address of the corresponding author: Artur Magnuszewski, Hydrology Department, University of Warsaw, Krakowskie Przedmiescie 30,00-927 Warszawa, Poland; e-mail: asmagnus@uw.edu.pl

\section{Introduction}

For the estimation of the total phosphorous load propagation in the catchment, there exist many methods starting from hydrological deterministic models to empirical regression formulas. In this paper we propose the use of a GIS approach which makes possible evaluation the potential load of the nutrients related to point sources at the sub-catchment scale and trace the load down the river system.

Anthropogenically derived pollutants, especially nutrients such as phosphorus and nitrogen, cause spatial variations in riverine nutrient export (Bricker et al. 2007, Russell et al. 2008, Kiedrzyńska and Zalewski 2012, Izydorczyk et al. 2013, Kiedrzyńska et al. 2014). Based on an ecohydrologic approach, we believe that many re- 
gional scale catchments and valley characteristics affect local hydrology, transport, and sediment yields on floodplains (Magnuszewski et al. 2005, Altinakar et al. 2006, Magnuszewski et al. 2007, Kiedrzyńska et al., 2008a), surface and groundwater quality (Kiedrzyńska et al. 2008b), habitat features, and aquatic biota (Frissell et al. 1986, Allan and Johnson 1997).

In addition to natural processes, nutrients originate from from both point sources and diffuse sources. The first type is related to urban and industrial areas, while the second is primarily related to agricultural practices. There is a growing need to understand the origin and propagation of nutrients at the catchment scale. The spatial and temporal complexity of catchment processes makes it difficult to obtain hydrologic measurements and observations at every spatial scale. However, monitoring programs can be optimized on the basis of a thorough understanding of catchment properties and processes, usually at the sub-catchment scale.

Today, the assessment of catchment conditions mostly is based on digital maps and remote sensing data which have become available in national databases. Large volumes of spatial data are processed with the use of geographical information systems and related technologies. Studies of the relationship between anthropogenic activity and catchment properties are usually focused on land use. Hetling et al. (1999) have presented an approach in which the input-output of nutrient loads has been used as an explanatory variable in the study of 10 large catchments in the USA. They found that during the 1970s, large discharges of wastewater were the dominant source of phosphorus $(\mathrm{P})$ in the analyzed catchments. This was linked to the inclusion of $P$ in soaps and detergents that began in the late 1940s (removal of $\mathrm{P}$ from these product formulations began in the 1980s).

In an extensive study of the relationship between river chemistry and catchment properties, performed by the U.S. Geological Survey under the National Water Quality Assessment (NAWQA) Program, it was found that intensive agriculture has an undoubtedly strong effect on the river chemistry. However, the most substantial impacts have been from human activities, measured as a percent of urbanization and popu- lation density which exert a significant influence on sediment associated chemical concentrations (Horowitz and Stephens 2008).

For contemporary water management policies, there is an increasing need to monitor the state of river at scales appropriate to management actions. This approach has been adopted as part of the European Union Water Framework Directive (WFD 2000/60/EC) which established an approach for Community Action in the field of water policy with the goal of achieving a 'good ecological status' for aquatic ecosystems by 2015. This approach also has been implemented in the U.S. Environmental Monitoring and Assessment Program (EMAP), and the Australian River Assessment System (AUSRIVAS) (Norris et al. 2007). Further, in the Baltic Sea region, the need to reduce riverine loads of phosphorus and nitrogen compounds as well as hazardous substances, is expressed in the Baltic Sea Action Plan (BSAP 2007).

Measurements of the relation between TP loads and river run-off volume $(\mathrm{H})$ in Poland shows that between 1999-2009 there has been an overall decline in TP loads; however, after 2003, the level stabilized - with the exception of the extremely wet year 2010 (Fig. 1).

Sapek (2008) explained that TP this pattern of TP decrease resulted from the intensive development of wastewater treatment plants (WWTPs), and the growing number of P-stripping installations. In Poland, there still remains a major need for water quality improvement in urban areas, Based on 2005 data, $75 \%$ of the volume of mu-

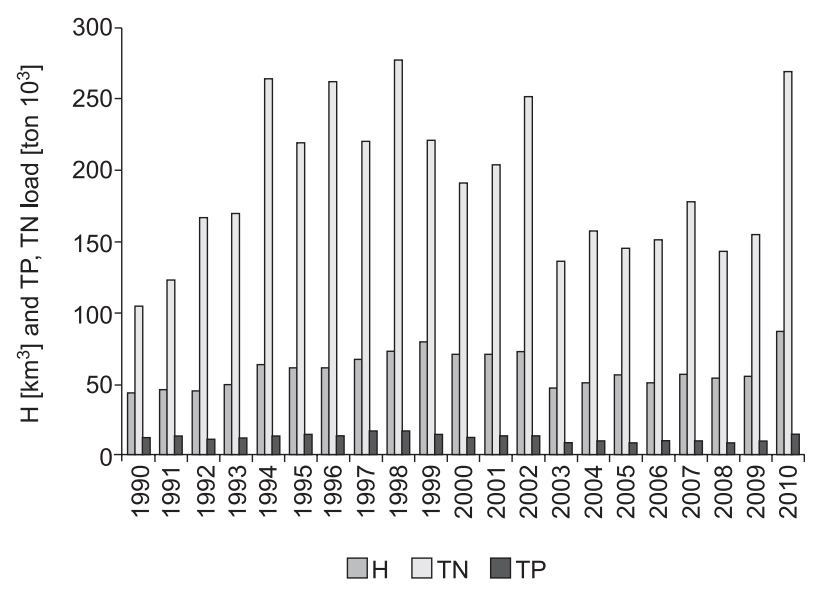

Fig. 1. River runoff and nutrients supplying Baltic Sea from Poland's territory in the period 1990-2010, H - river run-off $\left[\mathrm{km}^{3}\right], \mathrm{TN}$ - total nitrogen, and TP - total phosphorous [ton 103] (PCSO 2012) 
nicipal wastewater in Poland was produced by the 198 largest cities (National Council of Water Management for 2005).

The example of main features of landscape development in a regional scale of Wielkopolska with reference to socio-economic conditions and the processes of energy and matter flow in agroecosystems has been shown by Mizgajski (2007). In Poland, estimates of the nutrients sources and

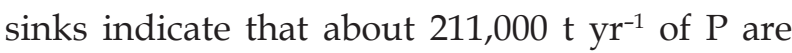
applied through agricultural practices whereas only about $55,000 \mathrm{t} \mathrm{yr}^{-1}$ are sold in produce. This indicates that the pool of agricultural $\mathrm{P}$ only is reduced by some $26 \%$ through the sale of food which in large proportion, supplies the $\mathrm{P}$ in urban areas. The final amount of $\mathrm{P}$ reaching the Baltic Sea comprises only about 5\% of the initial mass of P supplied by Polish agriculture (Sapek 2010).

A simple division of $\mathrm{P}$ sources into point and diffuse categories is not very clear in the cases of scattered settlements and poor sewerage programs. In Poland, according to 2009 census data, water supply and wastewater purification systems in urban and rural population show a disproportionate distribution. In urban areas, $84 \%$ of the population has access to municipal water supplies and wastewater treatment facilities, while only $23 \%$ of the rural population has access to wastewater treatment plants. This difference still exists despite the fact that between $2005-2009,26.3 \times 10^{3} \mathrm{~km}$ of sewage pipelines were added in the cities and $18.1 \times 10^{3} \mathrm{~km}$ in rural areas. Hence, progress in sanitation in rural areas is spectacular in comparison with 1995 (Table 1).

By 2015, plans call for the connection of an additional $4.6 \times 10^{6}$ people in rural areas to municipal sewerage systems. That amounts to around $30 \%$ of the whole rural population. Even so, some $5 \%$ of the urban population and $20 \%$ of the rural population will still be living in low standard housing that is not equipped with toilet facilities (Błaszczyk et al. 2011). Another factor is the diffuse settlement pattern in rural areas that makes the cost of building sewerage systems uneconomical. And, according to existing regulations, there is no obligation to connect a house to a newly installed municipal sewerage system. The high cost of adding connecting lines to municipal sewerage systems is an especially important aspect in areas of sparse settlement. Similar problems were reported by Jarvie et al. (2006) in the UK, where measures to reduce $\mathrm{P}$ inputs to rivers currently focus on reducing concentrations by the tertiary treatment (P-stripping) of effluents from large WWTPs that serve major urban centers. They believe that while P-stripping from these larger WWTPs may substantially reduce SRP (soluble reactive phosphorus) concentrations in river water, large fluxes of $P$ are expected to remain in the catchment due to the cumulative impact of the large numbers of small WWTPs upstream.

\section{Materials and methods}

The Pilica River is the largest left-bank tributary to the middle reach of the Vistula River, and it is $342 \mathrm{~km}$ long, with a catchment area of 9,258 $\mathrm{km}^{2}$. The catchment is located in central Poland, with the terrain elevation in the range 90-497 m above sea level. In the 1970s, in the middle course of the Pilica River (between 137 and $153 \mathrm{~km}$ of the river chainage) a large artificial lake - the Sulejów Reservoir - was installed. It has a length $15.5 \mathrm{~km}$, a maximum width of $2.1 \mathrm{~km}$, a surface area of 22 $\mathrm{km}^{2}$, and a total storage capacity 77.6 million $\mathrm{m}^{3}$. Long term average river inflow to the reservoir comes from the Pilica River $\left(\mathrm{Q}=22.8 \mathrm{~m}^{3} \mathrm{~s}^{-1}\right)$ and the tributary Luciąża River $\left(\mathrm{Q}=4.41 \mathrm{~m}^{3} \mathrm{~s}^{-1}\right)$; the mean water retention time is 33 days. The amount of sediment deposition in the reservoir has been estimated as $0.1 \times 10^{6} \mathrm{~m}^{3}$ annually (IMGW 2008). The Sulejów Reservoir suffers from significant eutrophication due to the supply of nutrient

Table 1. Use of the main sewerage systems in Poland years 1995-2009 (PCSO 2010)

\begin{tabular}{|c|c|c|c|}
\hline Year & $\begin{array}{c}\text { Urban } \\
\text { population } \\
\text { using } \\
\text { sewerage } \\
\text { systems }\end{array}$ & $\begin{array}{c}\text { Rural } \\
\text { population } \\
\text { using } \\
\text { sewerage } \\
\text { systems }\end{array}$ & $\begin{array}{c}\text { Length of the } \\
\text { main sewerage } \\
\text { systems }\end{array}$ \\
\cline { 2 - 4 } & \multicolumn{2}{|c|}{$[\%]$} & {$[\mathrm{km}]$} \\
\hline 1995 & 82.1 & 3.1 & 5,359 \\
\hline 2000 & 83.0 & 10.8 & 16,222 \\
\hline 2005 & 84.5 & 20.4 & 36,821 \\
\hline 2007 & 85.0 & 23.8 & 43,536 \\
\hline 2008 & 85.5 & 25.7 & 46,943 \\
\hline 2009 & 85.8 & 26.9 & 50,454 \\
\hline
\end{tabular}



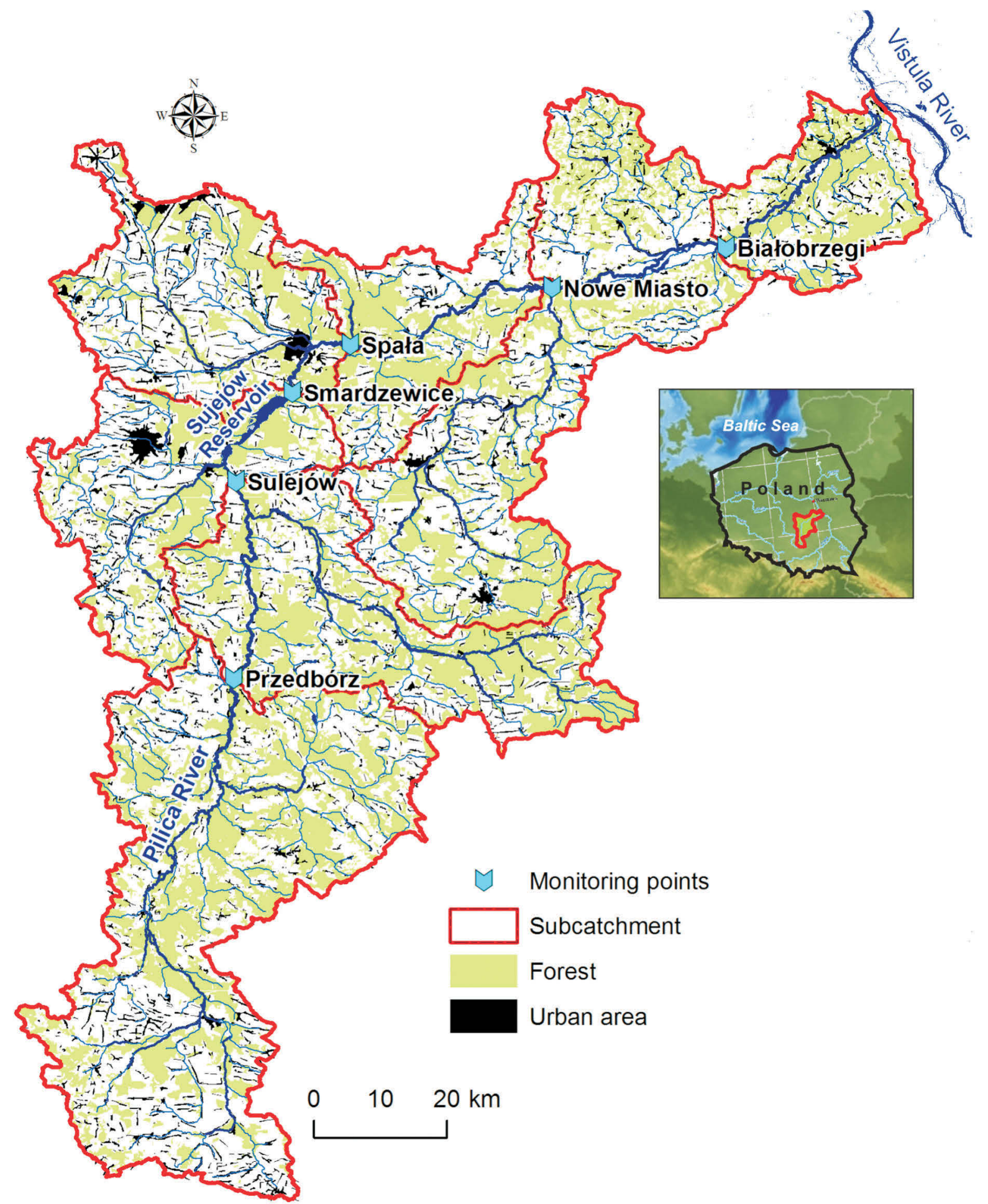

Fig. 2. General land cover and location of the monitoring points and sub-catchments in the Pilica River basin (central Poland)

compounds from both point and nonpoint (diffuse) sources. A particularly difficult problem for water managers has been the massive blooms of toxic algae (specifically cyanobacteria) which often occur in the summer (Tarczyńska et al. 2001, Izydorczyk et al. 2005).
Six monitoring points have been established at Przedbórz, Sulejów, Smardzewice, Spała, Nowe Miasto, and Białobrzegi to measure water and nutrient concentrations/fluxes (Fig. 2). For the Sulejów Reservoir there is a special interest in the station Smardzewice, which is located on the Pil- 
ica River reach below the dam. The hydrological information from the monitoring profiles comes from a network of hydrological gauges which are operated by the Institute of Meteorology and Water Management.

Water samples were collected over a one year period at the monitoring sites (between 19 May 2010 and 19 May 2011), every four days (90 samplings at each station, 540 samplings for all stations). Total phosphorus (TP) was analysed in unfiltered water samples by the addition of the oxidizing decomposition reagent Oxisolv (Merck) using a Merck MV 500 Microwave Digestion System and was determined by the ascorbic acid method (Greenberg et al. 1992).

Locations of WWTPs have been described by their WGS-84 geographical coordinates and expressed as a point with assigned attributes. That makes it possible to calculate the spatial characteristics related to WWTPs in sub-catchments units. The location of the WWTPs together with the volume of water they process is shown in Figure 3. The largest WWTP is located in Piotrków Trybunalski (having population of about 76,000 citizens), a city producing $14,500 \mathrm{~m}^{3}$ of treated wastewater per day (Kiedrzyńska et al. 2014). The wastewater contains $55 \mathrm{~kg}$ of TP and 1,170 kg of TN. Other large WWTPs are located in the cities of Tomaszów Mazowiecki (65,000 of citizens), and Warka (11,000 of citizen) (Fig. 3).

Kiedrzyńska et al. (2012) and Kiedrzyńska et al. (2014) have shown that the efficiency of sewage purification depends on the size of the WWTP. Small installations in the Pilica catchment release water with higher nutrient concentrations than the bigger and better equipped facilities. During low flow periods, the highest concentrations of TP $\left(5.12 \mathrm{mg} \mathrm{dm}^{3}\right)$ were observed at the outlet of the smallest WWTP. The volume of sewage water processed by different WWTPs in the sub-catchment boundaries, and the ratio of sewage volume to river run-off is provided in Table 2.

The boundaries of the Pilica River sub-catchments have been extracted from a National Hydrographic Map of Poland. The map CORINE-2006 was used to obtain the information on the sub-catchment land cover. Cartographic analysis was performed using the Ilwis 3.3 program. Three land classes, expressed as a relative percent of land cover, have been calculated for each of the sub-catchments located between the monitoring sites (Table 3). The large proportion of lakes in the Smardzewice sub-catchment is due to the Sulejów Reservoir. The Smardzewice

Table 2. Volume of processed wastewater by the different WWTPs and its share in the river run-off in the subcatchments (Kiedrzyńska et al. 2014)

\begin{tabular}{|c|c|c|c|c|c|}
\hline \multirow{2}{*}{$\begin{array}{l}\text { Name of moni- } \\
\text { toring profile }\end{array}$} & \multicolumn{4}{|c|}{ Volume of processed waste water by different WWTPs $\left[\mathrm{m}^{3} \mathrm{yr}^{-1}\right]$} & \multirow{2}{*}{$\begin{array}{c}\text { Percent of waste- } \\
\text { water in the river } \\
\text { total outflow }\end{array}$} \\
\hline & Industrial & Municipal & Domestic & Total & \\
\hline Przedbórz & 572,910 & $1,679,042$ & 121,357 & $2,373,309$ & 0.26 \\
\hline Sulejów & 9,524 & $1,012,988$ & 160,562 & $1,183,074$ & 0.07 \\
\hline Smardzewice & 115,046 & $5,691,703$ & 85,143 & $5,891,892$ & 0.38 \\
\hline Spała & 425,428 & $3,960,698$ & 249,577 & $4,635,703$ & 0.28 \\
\hline Nowe Miasto & 45,051 & 91,529 & 14,372 & 150,952 & 0.01 \\
\hline Białobrzegi & 380,208 & $2,663,677$ & 92,557 & $3,136,442$ & 0.14 \\
\hline Total & $1,555,534$ & $16,062,373$ & 723,968 & $18,341,875$ & 0.19 \\
\hline
\end{tabular}

Table 3. Characteristic of the Pilica River sub-catchments land cover between individual monitoring profiles (calculated from CORINE-2006 and PGI 2007 data)

\begin{tabular}{|l|c|c|c|c|c|}
\hline $\begin{array}{c}\text { Name of monitoring } \\
\text { profile }\end{array}$ & $\begin{array}{c}\text { Area } \\
{\left[\mathrm{km}^{2}\right]}\end{array}$ & $\begin{array}{c}\text { Lakes } \\
{[\%]}\end{array}$ & $\begin{array}{c}\text { Forest } \\
{[\%]}\end{array}$ & $\begin{array}{c}\text { Urbanisation } \\
{[\%]}\end{array}$ & $\begin{array}{c}\text { Floodplain area } \\
{[\%]}\end{array}$ \\
\hline Przedbórz & $2,545.2$ & 0.11 & 34.73 & 1.72 & 2.68 \\
\hline Sulejów & $1,390.5$ & 0.08 & 50.25 & 2.03 & 6.65 \\
\hline Smardzewice & 997.5 & 2.36 & 28.45 & 5.64 & 0.43 \\
\hline Spała & $1,034.1$ & 0.07 & 25.68 & 8.57 & 3.32 \\
\hline Nowe Miasto & 745.0 & 0.15 & 40.94 & 3.07 & 3.43 \\
\hline Białobrzegi & $1,943.7$ & 0.13 & 18.45 & 3.03 & 7.55 \\
\hline
\end{tabular}




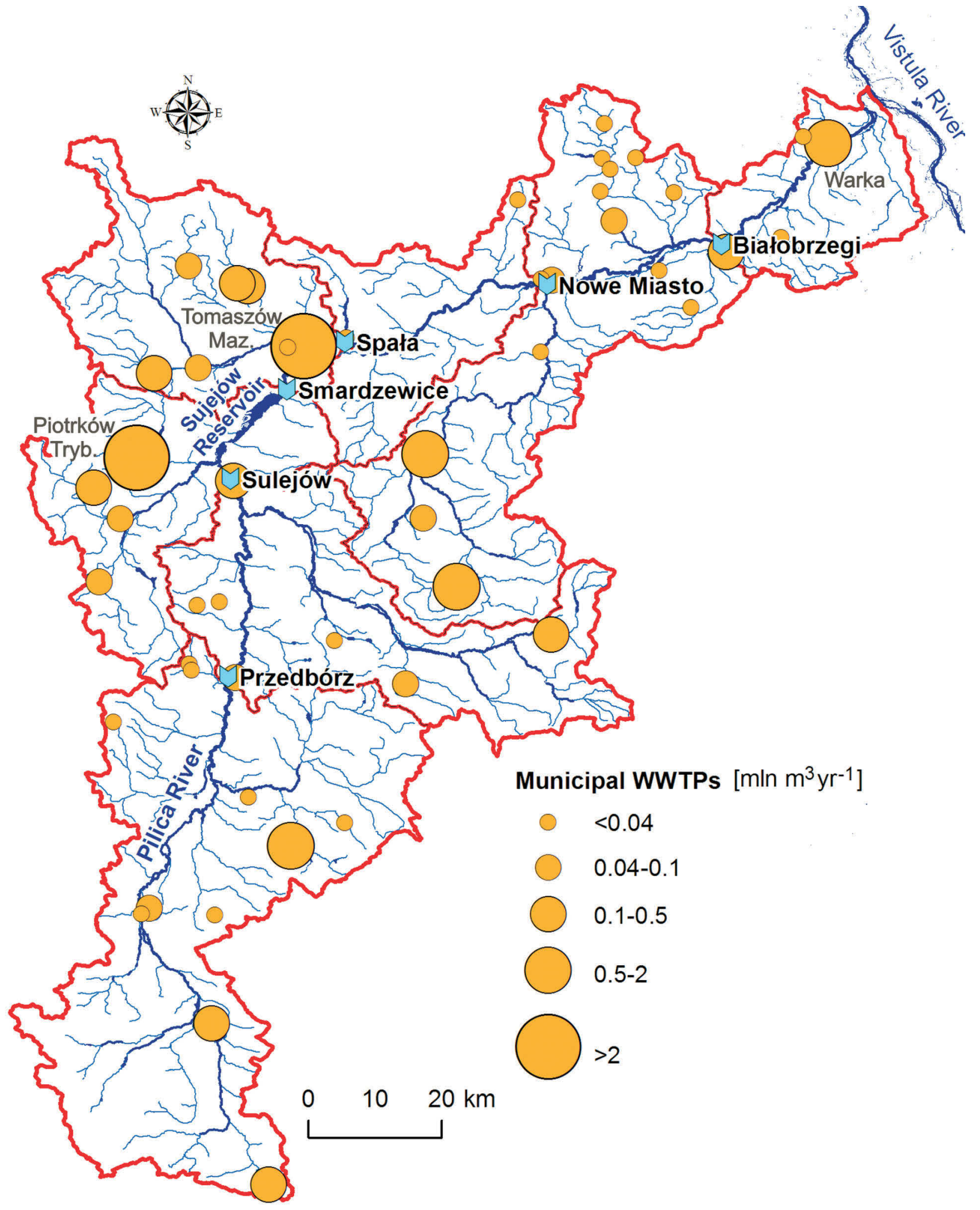

Fig. 3. Location and volume of wastewater outflows from municipal WWTPs in the Pilica River sub-catchments in 2010

and Spała sub-catchments, located in the central reach of the Pilica River, display relatively high levels of urbanization. Vast forest complexes are characteristic of Sulejów and Nowe Miasto sub-catchments. The area of the sub-catchments floodplains was calculated from a map of potential flooding prepared by the Polish Geological Institute (PGI 2007). The very small percentage 
of floodplain in the Smardzewice sub-catchment is due to the presence of the Sulejów Reservoir.

An overview of the relationship between the basin characteristics and nutrient losses has been done in the project EUROHARP, the river system's phosphorus concentration is explained in major parts by the rain intensity and discharges from agglomerations (Bouraoui et al. 2009). To avoid the influence of the catchment size on the relationship between catchment properties and nutrients flux, the independent and dependent variables should be relative. For this reason, we selected settlement density as a measure of anthropogenic impact at the catchment scale. This was calculated by dividing the number of people living in the catchment (obtained from the census records for the lowest administrative unit - gmina) by the catchment's area.

An important feature for nutrient flow is a measure of the connectivity between the source and the river network. The buffer zone map with the $10 \mathrm{~m}$ divisions has been calculated from the hydrographic vector map. Then the CORINE-2006 map with the classes 1.1 (dwellings) has been crossed with the buffer zone map. This map has been divided into sub-catchment boundaries, providing the average distance of a dwelling to the river network.

The potential load of the annual anthropogenic TP can be estimated (by an indirect method in GIS) as proportional to the number of people living in a given catchment. There is a wide literature on TP load estimation, and methods can vary from a single nutrient export coefficients to complex catchment models. In this study, a nutrient export coefficient value of $0.67 \mathrm{~kg} \mathrm{TP}_{\text {person }}{ }^{-1}$ $\mathrm{yr}^{-1}$ was used after Pieterse et al. (2003). Similar coefficient values have been obtained in the study on Rhine $\left(0.63 \mathrm{~kg}\right.$ TP person $\left.{ }^{-1} \mathrm{yr}^{-1}\right)$ and Elbe (0.72 kg TP person $\left.{ }^{-1} \mathrm{yr}^{-1}\right)$ (de Wit 2000).

\section{Results and discussion}

The population density is highest in the central part of the Pilica River catchment (Fig. 4). It grows from the Przedbórz sub-catchment (122 person $\mathrm{km}^{-2}$ ) to the Smardzewice sub-catchment (297 person $\mathrm{km}^{-2}$ ), and then decreases downstream.

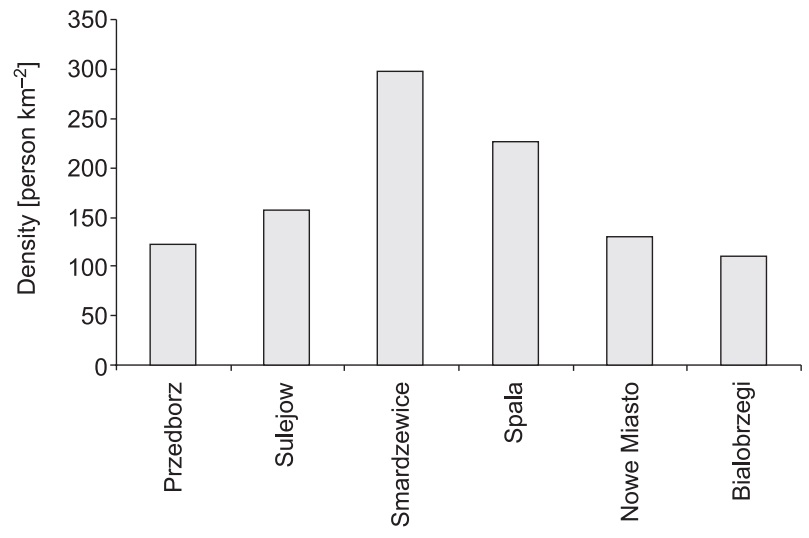

Fig. 4. Population density in the Pilica River sub-catchments

The average distance between a dwelling and the river network in the Pilica River is inversely related to population density (Fig. 4, 5). An exception is the Spała sub-catchment, where there is a relatively long distance between a dwelling and the river network $(1,947 \mathrm{~m})$, while at the same time the population density is relatively high (226 person $\left.\mathrm{km}^{-2}\right)$.

A comparison between the estimated and measured TP loads is shown in Figure 6. The estimated annual TP load increased downstream in the river from 210 ton TP in Przedbórz to 930 ton TP in Białobrzegi. This pattern also is reflected in the measured values. An exception is the decrease of measured TP load between the monitoring points in Sulejów (385 ton $\mathrm{TP} \mathrm{yr}^{-1}$ ) and Smardzewice (305 ton TP $\mathrm{yr}^{-1}$ ) which are separated by the Sulejów Reservoir. This indicates process of $\mathrm{P}$ trapping in the Sulejów Reservoir. From the Smardzewice sub-catchment downstream, the measured TP loads are lower than the estimated TP loads (Fig. 6).

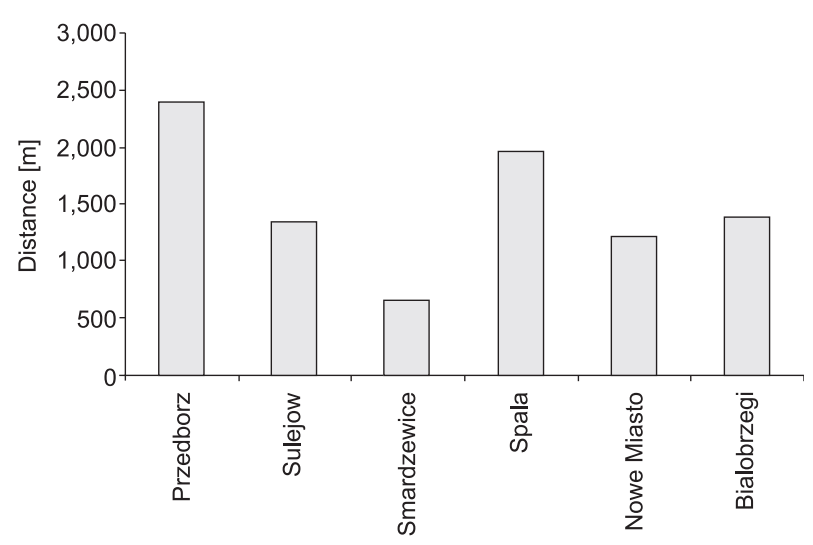

Fig. 5. Distance of the dwelling to the river network in the Pilica River sub-catchments obtained from CORINE-2006 and hydrographic buffer zone maps 


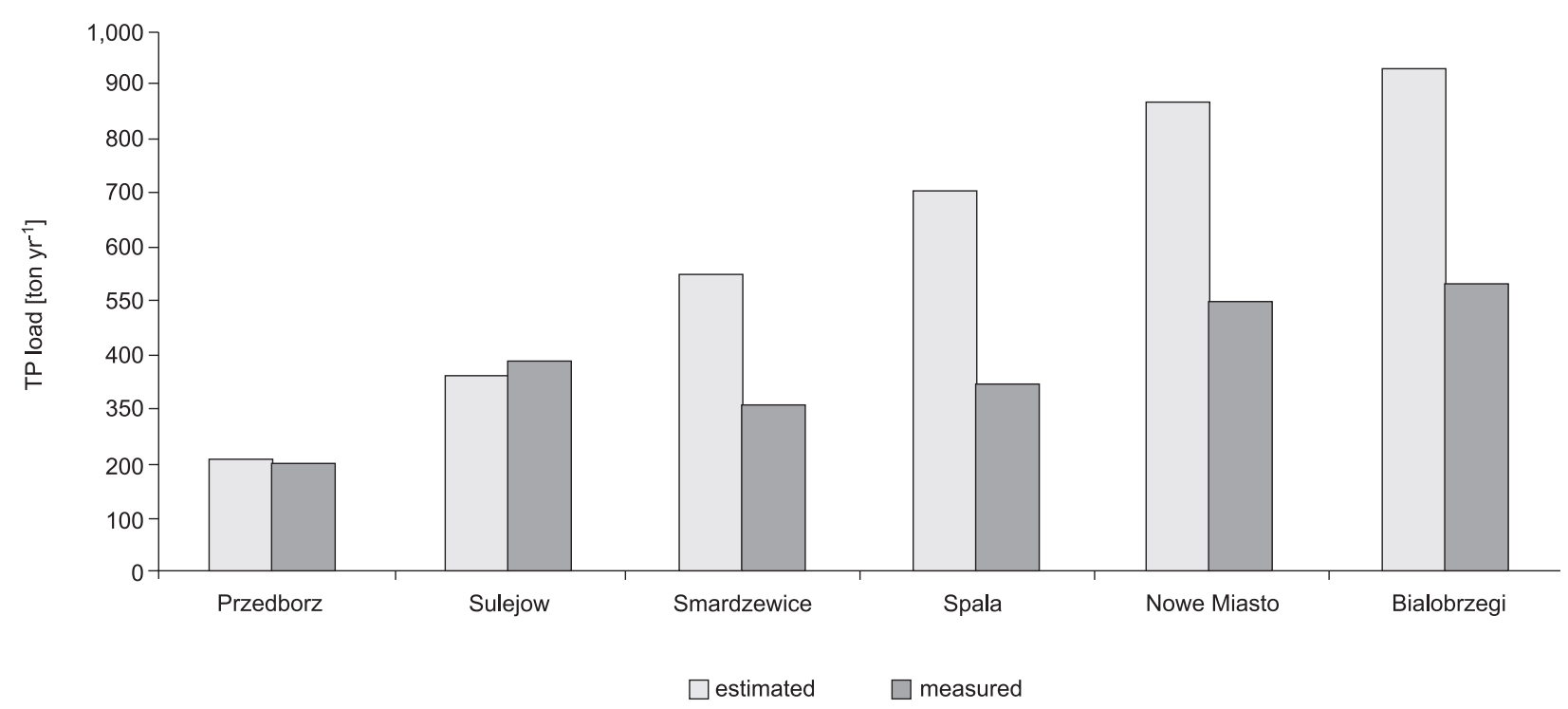

Fig. 6. Measured TP load in the period between 19 May 2010 and 19 May 2011 (Kiedrzyńska et al. 2014) and estimated TP load in monitoring points along the Pilica River located in the individual sub-catchments

The results from both GIS analysis and monitoring shows that the Sulejów Reservoir has been located in a subcatchment with the largest load of the TP; this feature determines the problem of reservoir eutrophication.

The aim of the study was to test an indirect GIS method used to estimate the magnitude and distribution of the total phosphorus load in a lowland river catchment augmented with a large water reservoir. The method is based on the eco-sociological characteristics of sub-catchments obtained from GIS data analysis. The results for TP obtained from GIS estimation at the sub-catchment level have been validated by the comparison with actual (measured) data from monitoring points.

The nutrient export derived from point and diffuse sources has scalar properties, meaning that there is a relationship between the magnitude of the source(s) and their generating processes. Wickham, Wade (2002) show that nutrient export coefficients multiplied by the area of a given land-cover class make it possible to estimate the nutrient load contributed by that land-cover class. Beaulac, Reckhow (1982) provide a conceptual basis for using the distributions of nutrient export coefficients stratified by land-cover class. Currently, the standard approach is to apply GIS analysis where phosphorus and nitrogen export coefficients are assigned to land-cover categories, and then aggregated across sub-catchments and broader geographic regions.
Sewerage systems are connected to the WWTPs which discharge the wastewater to the river network. These outlets can be easily located and monitored, since the amount of inflow and the properties of the water leaving the facilities are known. The outlets from the wastewater treatment plants can be mapped as "red points", showing the magnitude of the nutrient loads.

However, individual dwellings do not need an allowance, so the location and volume of sewage remains unknown. One possible approach is a GIS analysis where the total number of dwellings that were not connected to wastewater treatment plants within a region was multiplied by the average nutrient load per dwelling (Pieterse et al. 2003). However, there are also are some catchment properties which can complicate the simple scalar properties. These include: (1) nutrient loads are transformed by natural self-purification processes before reaching the outlet of the catchment or receiving water body; (2) the density of impervious surfaces is important for runoff generation and sediments transport (Arnold, Gibbons, 1996); (3) the pathway of nutrient fluxes is controlled by the spatial pattern of land-cover in the watershed (Jones et al. 2001).

To understand the mechanisms of nonpoint nutrient sources it is important to specify good diagnostic variables which describe both physiographic conditions and the nature of anthropogenic activity in the catchment. The study of nonpoint sources by Clapham et al. (1999) has shown 
that the variables describing catchment response to rainfall, such as precipitation characteristics, soil cover, and slope gradient, are weakly correlated with the nutrient loads at the mouth of the catchment. They show that good indices of anthropogenic activity are: land-use characteristics, population density, and air quality.

The results of this analysis show that the Smardzewice sub-catchment, due to its high population density and good connectivity between dwellings and the river network, has the highest potential for producing and adding TP to the Pilica River. A distinctive feature of the TP distribution down the Pilica River continuum is the decline in TP after passing through the Sulejów Reservoir. This is caused by the deposition of suspended sediment and its associated phosphorus in the reservoir (Urbaniak et al. 2012), and also as a result of the biological uptake of $P$. That function of the Sulejów Reservoir also has been described by Wagner, Zalewski (2000).

\section{Acknowledgements}

Financial support from the Polish Ministry of Science and Higher Education, Project No. 76691 is gratefully acknowledged. The analyses were partially conducted within the Polish Ministry of Science and Higher Education project NN305 365738 Analysis of point sources pollution of nutrients, dioxins and dioxin-like compounds in the Pilica River catchment and draw up of reclamation methods.

\section{References}

Allan J.D., Johnson L.B., 1997. Catchment-scale analysis of aquatic ecosystems. Freshwater Biology 37: 107-111.

Altinakar M., Kiedrzyńska E., Magnuszewski A., 2006. Modeling of inundation pattern at Pilica river floodplain, Poland. In: Demuth S., Gustard A., Planos E., Scatena F., Servat E. (eds), Climate Variability and Change Hydrological Impacts. IAHS Publ. 308: 579-585.

Arnold C.L., Gibbons, C.J., 1996. Impervious surface: the emergence of a key environmental indicator. Journal of the American Planning Association 62: 244-252.

Beaulac, M.N., Reckhow K.H., 1982. An examination of landuse-nutrient export relationships. Water Resources Bulletin 18: 1013-1024.

Błaszczyk P., Gromiec M., Miłaszewski R., 2011. Impact of the National Programme for Municipal Wastewater Treatment to meet the demand for sewerage services. Gaz, Woda i Technika Sanitarna 7-8: 251-253 (in Polish).
Bouraoui F., Grizzetti B.,. Adelsköld G., Behrendt H., de Miguel I., Silgram M., Gómez S., Granlund K., Hoffmann L., Kronvang B., Kværnø S., Lázár A., Mimikou M., Passarella G., Panagos P., Reisser H., Schwarzl B., Siderius C., Sileika A.S., Smit A. A. M. F. R., Sugrue R., VanLiedekerke M., Zaloudik J., 2009. Basin characteristics and nutrient losses: the EUROHARP catchment network perspective. Journal of Environmental Monitoring 11(3): 515-525.

Bricker S., Longstaff B., Dennison W., Jones A., Boicourt K., Wicks C., 2007. Effects of nutrient enrichment in the nation's estuaries: a decade of change. NOAA Coastal Ocean Program Decision Analysis Series No. 26. National Centers for Coastal Ocean Science, Silver Spring, MD.

BSAP, 2007. HELCOM Baltic Sea Action Plan has been adopted by Poland and other Baltic states at the Ministerial Conference held in Krakow on 15.11.2007 (http:/ / helcom.fi/baltic-sea-action-plan).

Clapham Jr W.B., Granat L., Holland M.M., 1999. Human activities in the drainage basin as sources of nonpoint pollutants. In: Thornton J.A. (ed.), Assessment and control of nonpoint source pollution of aquatic ecosystems. UNESCO, Paris.

Frissell C.A., Liss L.J., Warren C.E., Hurley M.D., 1986. A hierarchical framework for stream habitat classification: viewing streams in a watershed context. Environmental Management 10: 199-214.

De Wit M., 2000. Modelling nutrient fluxes from source to river load: a macroscopic analysis applied to the Rhine and Elbe basins. Hydrobiologia 410: 123-130.

Greenberg A.E., Clesceri L.S., Eaton A.D. (eds), 1992. Standard Methods for the Examination of Water and Wastewater. $18^{\text {th }}$ edition. American Public Health Association, Washington.

Hetling L.J., Jaworski N.A., Gerretson D.J., 1999. Comparison of nutrient input loading and riverine export fluxes in large watersheds. Water Science and Technology 39 (12): 189-196.

Horowitz A.J., Stephens V.C., 2008. The effects of landuse on fluvial sediment chemistry for the conterminous U.S. - Results from the first cycle of the NAWQA Program: Trace and major elements, phosphorus, carbon, and sulfur. Science of the Total Environment 400: 290-314.

IMGW, 2008. Study on sedimentation and reservoir volumeSulejów Reservoir, Warszawa, report documentation (in Polish).

Izydorczyk K., Frątczak W., Drobniewska A., Cichowicz E., Michalska-Hejduk D., Gross R., Zalewski M., 2013. A biogeochemical barrier to enhance a buffer zone for reducing diffuse phosphorus pollution-preliminary results. Ecohydrology and Hydrobiology 13: (2) 104-112.

Izydorczyk K., Tarczyńska M., Jurczak T., Mrówczyński J., Zalewski, M., 2005. Measurement of phycocyanin fluorescence as an online early warning system for cyanobacteria in reservoir intake water. Environmental Toxicology 20: $425-430$.

Jarvie H.P., Neal C., Withers P.J.A., 2006. Sewage-effluent phosphorus: A greater risk to river eutrophication than agricultural phosphorus? Science of the Total Environment 360: 246-253

Jones K.B., Neale A.C., Nash M.S., VanRemortel R.D., Wickham J.D., Riitters K.H., O'Neill R.V., 2001. Predicting nutrient and sediment loadings to streams from landscape metrics: a multiple watershed study from the United States mid-AtlanticRegion. Landscape Ecology 16: 301-312. 
Kiedrzyńska E., Kiedrzyński M., Urbaniak M., Magnuszewski A., Skłodowski M., Wyrwicka A., Zalewski M., 2014. Point sources of nutrient pollution in the lowland river catchment in the context of the Baltic Sea eutrophication. Ecological Engineering 70: 337-348, DOI 10.1016/j. ecoleng.2014.06.010.

Kiedrzyńska E., Zalewski M. 2012. Water Quality Improvement Through an Integrated Approach to Point and Non-Point Sources Pollution and Management of River Floodplain Wetlands. In: Voudouris, K. and Voutsa, D. (eds) Ecological Water Quality - Water Treatment and Reuse: 325-342. Open Access InTech. Rijeka, Croatia. http:// www.intechopen.com/books/ecological-water-quality-water-treatment-and-reuse/water-quality-improvement-through-an-integrated-approach-to-point-andnon-point-sources-pollution-an

Kiedrzyńska E., Urbaniak M., Kiedrzyński M., Skłodowski, M., Zalewski, M., 2012. Point sources of pollution as a threat to water quality Pilica. Gaz, Woda $i$ Technika Sanitarna 6: 254-256. (in Polish).

Kiedrzyńska E., Kiedrzyński M., Zalewski M., 2008a. Flood sediment deposition and phosphorus retention in a lowland river floodplain: impact on water quality of a reservoir, Sulejów, Poland. Ecohydrology and Hydrobiology 8 (2-4): 281-289.

Kiedrzyńska E., Wagner-Łotkowska I., Zalewski M., 2008b. Quantification of phosphorus retention efficiency by floodplain vegetation and a management strategy for a eutrophic reservoir restoration. Ecological Engineering 33: $15-25$.

Magnuszewski A., Kiedrzyńska E., Wagner-Łotkowska I., Zalewski, M. 2005. Immobilising of Sediments in a Lowland River Floodplain. In: Altinakar, M.S., Czernuszenko, W., Rowiński, P.M. and Wang S.S.Y. (eds) Computational Modeling for the Development of Sustainable Water-Resources Systems in Poland. US-Poland Technology Transfer Program. Publications of the Institute of Geophysics Polish Academy of Sciences. Monographic Volume E-5, 387: 239-260.

Magnuszewski A., Kiedrzyńska E., Wagner-Łotkowska I., Zalewski M., 2007. Numerical modelling of material fluxes on the floodplain wetland of the Pilica River, Poland. In: Okruszko T., Szatylowicz J., Miroslaw-Swiatek D., Kotowski W., Maltby E. (eds), Wetlands: Monitoring, Modelling and Management. A.A. Balkema Publishers - Taylor and Francis Group. The Netherlands 205-210.

Mizgajski A., 2007. Development of rural landscape in Wielkopolska in reference to metabolism of agroecosystems. Quaestiones Geographicae 26A: 39-51.

Newhama L.T.H., Letcher R.A., Jakeman A.J., Kobayashi T., 2004. A framework for integrated hydrologic, sediment and nutrient export modelling for catchment-scale management. Environmental Modelling and Software 19(2004): 1029-1038.

Norris R.H., Linke S., Prosser I., Young W.J., Liston P., Bauer N., Sloane N., Dyer F., Thoms M., 2007. Very-broad-scale assessment of human impacts on river condition. Freshwater Biology 52: 959-976.

PCSO, 2010. Polish Central Statistical Office. Statistical Yearbook of the Polish Republic in 2009. Warsaw. Poland. (in Polish).

PCSO, 2012. Polish Central Statistical Office. Environment Protection 2012. (in Polish).

PGI, 2007. Polish Geological Institute, Map of areas at risk of flooding in Poland. Państwowy Instytut Geologiczny, Warsaw. Poland

Pieterse N.M., Bleuten W. Jørgensen S.E., 2003, Contribution of point sources and diffuse sources to nitrogen and phosphorus loads in lowland river tributaries. Journal of Hydrology 27: 1213-225.

Russell M.J., Weller D.E., Jordan T.E., Sigwart K.J., Sullivan K.J., 2008. Net anthropogenic phosphorus inputs: spatial and temporal variability in the Chesapeake Bay region. Biogeochemistry 88: 285-304.

Sapek A., 2008. Sources of the substances transported by the rivers to the Baltic Sea. Woda Środowisko Obszary Wiejskie 8, 2a(23): 151-161.

Sapek A., 2010. Polish agriculture and water quality protection, with an emphasis on the Baltic Sea. Woda Środowisko Obszary Wiejskie 10, 1(29): 175-200.

Tarczyńska M., Romanowska-Duda Z., Jurczak T., Zalewski M., 2001. Toxic cyanobacterial blooms in a drinking water reservoir-causes, consequences and management strategy. Water Science and Technology: Water Supply 1(2): 237-246.

Urbaniak M., Kiedrzyńska E., Zalewski M. 2012. The role of a lowland reservoir in the transport of micropollutants, nutrients and the suspended particulate matter along the river continuum. Hydrology Research 43.4: 400-411.

Wagner I., Zalewski M., 2000. Effect of hydrological patterns of tributaries on biotic processes in a lowland reservoir consequences for restoration. Ecological Engineering 16: 79-90.

Water Framework Directive (2000/60/EC) of the European Parliament and of the Council establishing a framework for the Community action in the field of water policy. Official Journal L327, P.0001-0073(22/12 2000).

Wickham J.D., Wade T.G., 2002. Watershed level risk assessment of nitrogen and phosphorus export. Computers and Electronics in Agriculture 37: 15-24. 